\title{
Assessment of Surfactant Modified Activated Carbon for Improving Water Quality
}

\author{
Kamoru A. Salam \\ Department of Chemical Engineering, Faculty of Engineering, University of Abuja, Abuja, Nigeria \\ Email: kamorusalam@gmail.com
}

How to cite this paper: Salam, K.A. (2019) Assessment of Surfactant Modified Activated Carbon for Improving Water Quality. Journal of Encapsulation and Adsorption Sciences, 9, 13-34. https://doi.org/10.4236/jeas.2019.91002

Received: February 13, 2019

Accepted: March 11, 2019

Published: March 14, 2019

Copyright $\odot 2019$ by author(s) and Scientific Research Publishing Inc. This work is licensed under the Creative Commons Attribution International License (CC BY 4.0).

http://creativecommons.org/licenses/by/4.0/

(c) (i) Open Access

\begin{abstract}
Effluents containing inorganic contaminants are releasing into the environment untreated despite being hazardous to man and environment. It is costly and unsustainable to use conventional methods to remove them from dilute aqueous solution. Adsorption involving granular activated carbon is an alternative method for treating such effluents. Granular activated carbon is structurally strong, highly resistance to attrition and wearing, large and can easily separate from the effluents. However, its surface is highly hydrophobic and has little surface charge thereby reducing its adsorption capacity for anion or cation. This article reviews surfactant modification of activated carbon to enhance its adsorption capacity for inorganic contaminants and key factors affecting the adsorption efficiency. They include initial concentration of contaminants, contact time, solution $\mathrm{pH}$, solution temperature, adsorbent concentration, ionic strength, competing ions, type of surfactant, and surfactant concentration. The modified activated carbon usually shows maximum contaminant uptake around its critical micelles concentration. Surfactant modification reduces specific surface area and/or micro pore volume but hot $\mathrm{NaOH}$ or $\mathrm{HNO}_{3}$ treatment before surfactant modification minimises this drawbacks and increases the net surface charge. Overall, surfactant modification is a simple but efficient method of enhancing adsorption capacity of activated carbon for removing anion or cation from aqueous solution. However, a handful publication is available on the regeneration of the spent (saturated) surfactant modified activated carbons. Hence, more research efforts should be directed towards proper regenerating reagents and the optimise conditions such as contact time, concentration, and temperature for regenerating spent modified activated carbons.
\end{abstract}

\section{Keywords}

Surfactant, Modification, Adsorption, Activated Carbon, Inorganic Contaminants Regenerating 


\section{Introduction}

Massive industrial, domestic, agricultural, medical and technological applications of heavy metals contribute to their prevalence in the environment [1]. Anionic contaminants' main sources are widely varied. Perchlorate main sources include untreated effluents containing perchlorate salts from manufacturing of matches, airbags, explosives etc. [2] [3]. Byproduct of drinking water disinfection accounts for the main source of bromate contamination [4]. Nitrate contaminates environment mainly through untreated run off from fertilizer, septic tank and sewage [4] [5] while untreated discharge from steel and pulp mills accounts for major chromium released into the environment [4] [6].

According to United State Environmental Protection Agency, National Primary Drinking Water Regulations [4] the maximum contaminant level (MCL) in primary drinking water for inorganic contaminants are: arsenic, $0.10 \mathrm{mg} / \mathrm{L}$; cadmium, $0.005 \mathrm{mg} / \mathrm{L}$; lead, $0.015 \mathrm{mg} / \mathrm{L}$; chromium, $0.1 \mathrm{mg} / \mathrm{L}$, mercury, 0.002 $\mathrm{mg} / \mathrm{L}$; bromate, $0.1 \mathrm{mg} / \mathrm{L}$; nitrate, $10 \mathrm{mg} / \mathrm{L}$; chromium (total), $0.1 \mathrm{mg} / \mathrm{L}$ etc. In addition, they are hazardous to human health if consumed above the stated MCL. Arsenic causes skin damage, problems with circulatory systems, increased risk of getting cancer; cadmium causes kidney damage; lead causes kidney problem and high blood pressure in adults but delays physical and metal developments in infants and children; chromium causes allergic dermatitis; mercury causes kidney problem; bromate is carcinogen; chromium causes allergic dermatitis while excess intake of nitrate above MCL could lead to death in infant if left untreated.

Despite these potential health hazards of inorganic contaminants to man and negative impact to the environment, over $80 \%$ of the wastewater globally generated and over $95 \%$ in some least developed countries is released into the environment untreated [7]. This has attracted public concerns and motivated investigations into a sustainable treatment of cations or anions containing effluents.

The conventional methods of removing water contaminants from effluents include ion exchange, evaporation, chemical precipitation, membrane separation, chemical oxidation or reduction, electrochemical treatment, reverse osmosis [8] [9] [10]. However, these methods have disadvantages including lack of specificity and ineffective at low concentration [11], fouling of membrane by slightly soluble components [12] and high cost [10] [11]. In addition they need large footprint, sludge dewatering facilities, highly skilled operators and multiple basin configurations [13].

Similarly, adsorption involving nano-adsorbents or powdered activated carbon is hardly used due to operational problems. This includes complex and costly synthesis, turbidity inducement and separation difficulty [14] [15] [16]. In contrast, granular activated carbons due to their large size and hardness can be easily separated from aqueous media, do not cause turbidity in the treated water but have relatively low specific surface area. Besides, both powdered and granular activated carbons have low adsorption capacities for inorganic (cations or 
anions) contaminants due to their little active binding sites (surface functional groups) for such contaminants.

Considering the fact that activated carbon's surface is highly hydrophobic [17] [18] surfactant can be anchored on it using its hydrophobic group while its hydrophilic group tends towards the aqueous phase and ultimately determines its net surface charge [17] [19]. Modification of activated carbon with cationic surfactant makes its net surface charge positive [20] [21] [22] but using anionic surfactant makes it negative [23] [24]. In addition, keeping the $\mathrm{pH}$ of surfactant modified activated carbon system below or above $\mathrm{pHpzc}$ ( $\mathrm{pH}$ at which its surface charge equals zero) can alter the net surface charge from positive to negative or vice versa [20] [21] [22]. This flexibility will promote regeneration of spent (saturated) modified activated carbons.

This article reviews the use of surfactant modified activated carbons for adsorption of anions or cations from aqueous solutions, environmental factors and surfactant properties required to improve the process efficiency, drawbacks of the surfactant modified activated carbon and ways to minimise them. The author also suggests areas required more research effort.

\section{Applications of Surfactant Modified AC in Water Treatment}

Granular activated carbon is structurally strong, highly resistance to attrition and wearing [25]. These compelling characteristics together with their large size will make them easily separated from the effluents. But they are commonly used for adsorption of organic contaminants from gaseous and/or liquid mixtures due to their large hydrophobic surface. Inorganic contaminants and heavy metals usually exist in solution as ions or hydrous ionic complex [19] making activated carbon almost less effective for removing them. One technique of enhancing activated carbon surface for adsorption of inorganic contaminants is surfactant surface modification. This approach is more appealing due to its flexibility and simplicity

\subsection{Adsorption of Inorganic Contaminants}

Previous investigations show that surfactant surface modification of activated carbon is possible and effective for enhancing its adsorption capacity for removing inorganic contaminant from aqueous media. Table 1 clearly shows that percentage cation or anion removed by surfactant modified activated carbons is generally greater than unmodified (virgin) activated carbon at the same experimental conditions. This higher uptake capacity is consistent for the surfactant modified activated carbons regardless of their parent sources and whether powdered or granular.

Anh et al. [23] compared the specific uptake of Cd (II) ions by surfactant modified activated carbon with unmodified (virgin) one. At pH 6, initial Cd (II) concentration $(100 \mathrm{mg} / \mathrm{L}), 20^{\circ} \mathrm{C}$ and $120 \mathrm{~min}$ contact, the order of specific uptake obtained are sodium dodecyl sulphate (SDS) modified activated carbon, 
Table 1. Effect of surfactant modification on adsorption capacity of activated carbon.

\begin{tabular}{|c|c|c|c|c|c|c|c|c|c|c|}
\hline Contaminant & $\begin{array}{l}\text { Surfactant, } \\
\text { concentration. } \\
(\mathrm{g} / \mathrm{L})\end{array}$ & Solution $\mathrm{pH}$ & $\begin{array}{c}\text { Initial conc. } \\
\text { or range } \\
(\mathrm{mg} / \mathrm{L})\end{array}$ & $\begin{array}{l}\text { Contact } \\
\text { time } \\
(\mathrm{min})\end{array}$ & $\begin{array}{l}\text { Agitation } \\
\text { (rpm) }\end{array}$ & $\begin{array}{l}\text { Temp. } \\
\text { (C) }\end{array}$ & Kinetic model & Isotherm & $\begin{array}{c}\text { Contaminant } \\
\text { removed } \\
(\% \text { or } \mathrm{mg} / \mathrm{g})\end{array}$ & References \\
\hline \multirow{4}{*}{ Cd (II) } & $\begin{array}{l}\text { SDS, } 10.1, \\
4.28^{*} \mathrm{CMC}\end{array}$ & 6 & 100 & 120 & 100 & 20 & $\begin{array}{l}\text { Pseudo second } \\
\text { order }\end{array}$ & Freundlich & 22.3 & Ahn et al. [23] \\
\hline & $\begin{array}{l}\text { SDBS, } 10.1 \\
10.64^{*} \mathrm{CMC}\end{array}$ & 6 & 100 & 120 & 100 & 20 & $\begin{array}{l}\text { Pseudo second } \\
\text { order }\end{array}$ & Freundlich & 17.53 & Ahn et al. [23] \\
\hline & $\begin{array}{l}\text { DSS, } 10.1 \\
5.94^{*} \mathrm{CMC}\end{array}$ & 6 & 100 & 120 & 100 & 20 & $\begin{array}{l}\text { Pseudo second } \\
\text { order }\end{array}$ & Freundlich & 17.31 & Ahn et al. [23] \\
\hline & $\begin{array}{l}\text { Virgin activated } \\
\text { carbon }\end{array}$ & 6 & 100 & 120 & 100 & 20 & $\begin{array}{l}\text { Pseudo second } \\
\text { order }\end{array}$ & Freundlich & 2.47 & Ahn et al. [23] \\
\hline \multirow{2}{*}{ Cd (II) } & $\begin{array}{l}\text { SDBS, } 30.7 \\
73.4^{*} \mathrm{CMC}\end{array}$ & $4.5-7.2$ & $10-100$ & 1440 & - & 25 & - & Langmuir & $44.2^{\mathrm{a}}$ & Sun et al. [24] \\
\hline & $\begin{array}{l}\text { Virgin activated } \\
\text { carbon }\end{array}$ & $4.5-7.2$ & $10-100$ & 1440 & - & 25 & - & Langmuir & 6.8 & Sun et al. \\
\hline Co (II) & $\begin{array}{l}\text { SDS, } 3.54 \\
1.5^{\star} \mathrm{CMC}\end{array}$ & 7 & $20-100$ & 90 & 250 & 40 & $\begin{array}{l}\text { Pseudo second } \\
\text { order }\end{array}$ & Langmuir & 51 & $\begin{array}{c}\text { Kakavandi } \\
{[26]}\end{array}$ \\
\hline \multirow{2}{*}{ Bromate } & $\begin{array}{c}\text { CTAC, } 0.64 \\
1.26^{\star} \mathrm{CMC}\end{array}$ & 3 & $2-20$ & 1440 & - & 25 & $\begin{array}{l}\text { Pseudo second } \\
\text { order }\end{array}$ & Langmuir & 38.02 & $\begin{array}{c}\text { Chen et al. } \\
\text { [25] }\end{array}$ \\
\hline & $\begin{array}{l}\text { Virgin activated } \\
\text { carbon }\end{array}$ & 3 & $2-20$ & 1440 & - & 25 & $\begin{array}{l}\text { Pseudo second } \\
\text { order }\end{array}$ & Langmuir & 7.02 & $\begin{array}{c}\text { Chen et al. } \\
\text { [25] }\end{array}$ \\
\hline Bromate & $\begin{array}{c}\text { CTAC, } 0.64 \\
2^{*} \mathrm{CMC}\end{array}$ & - & $1-100$ & 720 & - & - & $\begin{array}{c}\text { Pseudo second } \\
\text { order }\end{array}$ & Langmuir & 35.8 & $\begin{array}{c}\text { Farooqet al. } \\
\quad[22]\end{array}$ \\
\hline \multirow{3}{*}{ Bromate } & $\begin{array}{c}\mathrm{CPC}, 0.68 \\
2^{\star} \mathrm{CMC}\end{array}$ & - & $1-100$ & 720 & - & - & $\begin{array}{l}\text { Pseudo second } \\
\text { order }\end{array}$ & Langmuir & 34.2 & $\begin{array}{l}\text { Farooqet al. } \\
\quad[22]\end{array}$ \\
\hline & $\begin{array}{c}\text { CTAB, } 0.729 \\
2^{\star} \mathrm{CMC}\end{array}$ & - & $1-100$ & 720 & - & - & $\begin{array}{l}\text { Pseudo second } \\
\text { order }\end{array}$ & Langmuir & 13.1 & $\begin{array}{c}\text { Farooq et al. } \\
\quad[22]\end{array}$ \\
\hline & $\begin{array}{l}\text { Virgin activated } \\
\text { carbon }\end{array}$ & - & $1-100$ & 720 & - & - & $\begin{array}{l}\text { Pseudo second } \\
\text { order }\end{array}$ & Langmuir & $\sim 13.1$ & $\begin{array}{c}\text { Farooq et al. } \\
{[22]}\end{array}$ \\
\hline \multirow{2}{*}{ Nitrate } & $\begin{array}{l}\text { CTAB, } 10.9 \\
33.3^{*} \mathrm{CMC}\end{array}$ & 5.6 & 100 & 5 & 250 & 25 & $\begin{array}{c}\text { Pseudo second } \\
\text { order }\end{array}$ & Langmuir & $83.3 ; 60 \%$ & $\begin{array}{c}\text { Allalouet al. } \\
\text { [28] }\end{array}$ \\
\hline & $\begin{array}{l}\text { Virgin activated } \\
\text { carbon }\end{array}$ & 5.6 & 100 & 5 & 250 & 25 & $\begin{array}{c}\text { Pseudo second } \\
\text { order }\end{array}$ & Langmuir & $14 \%$ & $\begin{array}{c}\text { Allalou et al. } \\
\text { [28] }\end{array}$ \\
\hline Nitrate & $\begin{array}{c}\text { CTAB, } 0.164 \\
0.5^{*} \mathrm{CMC}\end{array}$ & 7 & $40-200$ & 120 & 200 & 25 & $\begin{array}{c}\text { Pseudo second } \\
\text { order }\end{array}$ & Langmuir & $21.5^{\mathrm{b}}$ & $\begin{array}{c}\text { Mazarji et al. } \\
\text { [27] }\end{array}$ \\
\hline \multirow{2}{*}{ Nitrate } & CPMG, 2.5 & $6.5-6.8$ & $25-376$ & 90 & 150 & 23 & $\begin{array}{l}\text { Pseudo second } \\
\text { order }\end{array}$ & Langmuir & 26 & Cho et al. [29] \\
\hline & $\begin{array}{l}\text { Virgin activated } \\
\text { carbon }\end{array}$ & $6.5-6.8$ & $25-376$ & 90 & 150 & 23 & $\begin{array}{l}\text { Pseudo second } \\
\text { order }\end{array}$ & Langmuir & 14.3 & Cho et al. [29] \\
\hline \multirow{2}{*}{$\mathrm{Cr}(\mathrm{VI})$} & CPMG, 2.5 & $6.5-6.8$ & $25-376$ & 90 & 150 & 23 & $\begin{array}{l}\text { Pseudo second } \\
\text { order }\end{array}$ & Langmuir & 81 & Cho et al. [29] \\
\hline & $\begin{array}{l}\text { Virgin activated } \\
\text { carbon }\end{array}$ & $6.5-6.8$ & $25-376$ & 90 & 150 & 23 & $\begin{array}{l}\text { Pseudo second } \\
\text { order }\end{array}$ & Langmuir & 55 & Cho et al. [29] \\
\hline \multirow{3}{*}{$\mathrm{Cr}(\mathrm{VI})$} & $\begin{array}{c}\text { HDTMA, } 0.168 \\
0.5^{*} \mathrm{CMC}\end{array}$ & - & $10-200$ & 180 & 150 & 20 & $\begin{array}{l}\text { Pseudo second } \\
\text { order }\end{array}$ & Langmuir & 4.06 & Choi et al. [17] \\
\hline & $\begin{array}{c}\mathrm{CPC}, 0.161 \\
0.5^{*} \mathrm{CMC}\end{array}$ & - & $10-200$ & 180 & 150 & 20 & $\begin{array}{c}\text { Pseudo second } \\
\text { order }\end{array}$ & Langmuir & 3.70 & Choi et al. [17] \\
\hline & $\begin{array}{l}\text { Virgin activated } \\
\text { carbon }\end{array}$ & - & $10-200$ & 180 & 150 & 20 & $\begin{array}{l}\text { Pseudo second } \\
\text { order }\end{array}$ & Langmuir & 1.28 & Choi et al. [17] \\
\hline Perchlorate & $\begin{array}{c}\text { CTAC, } 1.6 \\
5^{*} \mathrm{CMC}\end{array}$ & $\sim 6.7$ & $5-50$ & 120 & 120 & 60 & & Langmuir & 55.3 & $\begin{array}{c}\text { Tang et al. } \\
{[21]}\end{array}$ \\
\hline
\end{tabular}

${ }^{\mathrm{a}}$ Treatment with $\mathrm{HNO}_{3}$ before SDBS modification; ${ }^{\mathrm{b}}$ Treatment with $\mathrm{NaOH}$ before CTAB modification. 
$22.3 \mathrm{mg} / \mathrm{g}>$ sodium dodecyl benzene sulfonate (SDBS) modified activated carbon, $17.53 \mathrm{mg} / \mathrm{g}>$ dioctyl sulfocuccinate sodium (DSS) modified activated carbon, $17.31 \mathrm{mg} / \mathrm{g}>$ virgin activated carbon, $2.47 \mathrm{mg} / \mathrm{g}$. Similarly, Kakavandi et al. [26] observed enhancement in specific uptake of Co (II) ions by SDS modified activated carbon reaching a maximum specific uptake of $51 \mathrm{mg} / \mathrm{g}$.

Sun et al. [24] worked on $\mathrm{HNO}_{3} / \mathrm{SDBS} /$ activated carbon system for adsorption of Cd (II) ion from aqueous solution. The specific Cd (II) ion uptake obtained are $\mathrm{HNO}_{3}-\mathrm{SDBS}$ modified activated carbon, $44.2 \mathrm{mg} / \mathrm{g}>\mathrm{SDBS}$ modified activated carbon, $26.6 \mathrm{mg} / \mathrm{g}>\mathrm{HNO}_{3}$ modified activated carbon, $22.8 \mathrm{mg} / \mathrm{g}>$ virgin activated carbon, $6.78 \mathrm{mg} / \mathrm{g}$ at optimum modification conditions: $\mathrm{HNO}_{3}$ concentration $(3.29 \mathrm{~mol} / \mathrm{L})$, SDBS concentration $(30,700 \mathrm{mg} / \mathrm{L})$ and $76^{\circ} \mathrm{C} . \mathrm{HNO}_{3}$ was used to treat the activated carbon before SDBS modification.

Surfactant modified activated carbons equally work effectively for enhancing adsorption of anions from aqueous solutions. Chen et al. [25] compared the adsorption capacity of cetyltrimethyl ammonium chloride (CTAC) modified activated carbon with virgin activated carbon for bromate uptake from aqueous solution. They observed CTAC modified activated carbon produced specific bromate uptake of $38 \mathrm{mg} / \mathrm{g}$ which was greater than $7.02 \mathrm{mg} / \mathrm{g}$ for the virgin activated carbon. Similarly, bromate specific uptake observed by Farooq et al. [22] are CTAC modified activated carbon, $35.8 \mathrm{mg} / \mathrm{g}>$ cetylpyridinium chloride (CPC) modified activated carbon, $34.2 \mathrm{mg} / \mathrm{g}>$ cetyltrimethylammonium bromide $(\mathrm{CTAB})$ modified activated carbon, $13.1 \mathrm{mg} / \mathrm{g}>$ virgin activated carbon, $\sim 13 \mathrm{mg} / \mathrm{g}$ at $12 \mathrm{~h}$ contact.

Other researchers reported enhancement in percentage nitrate removed by CTAB modified activated carbon [27] [28] and percentage perchlorate removed by CTAC modified activated carbon [21] compared with virgin activated carbon.

Cho et al. [29] has shown the possibility of enhancing adsorption capacity of activated carbon for nitrate and Cr (VI) from aqueous solution using quaternary ammonium-containing polymer. They observed that the cationic [3-(methacryloylamino)propyl]-trimethylammonium chloride modified activated carbon (CPMG) has specific nitrate uptake of $26 \mathrm{mg} / \mathrm{g}$ which was greater than $14.3 \mathrm{mg} / \mathrm{g}$ obtained for the virgin activated carbon. For Cr (VI), specific uptake of $81 \mathrm{mg} / \mathrm{g}$ was recorded for the modified activated carbon compared to $55 \mathrm{mg} / \mathrm{g}$ obtained for the virgin activated carbon.

Table 1 shows that that pseudo second order rate model properly describes the adsorption kinetic data of the modified activated carbons. Langmuir adsorption isotherm commonly fit properly the equilibrium adsorption data than the Freundlich isotherm for inorganic ions (cations and anions) adsorption onto the surface of surfactant modified activated carbons.

Table 2 clearly shows that surfactant modification causes reduction in BET specific surface area and/or micro pore volume. This is due to pore blockage as the surfactant anchors its hydrophobic group onto the activated carbon via the micropores. Allalou et al. [28] observed that a virgin activated carbon with initial 
Table 2. Effect of pre-treatment and surfactant modification on the surface area and pore volume.

\begin{tabular}{|c|c|c|c|c|c|c|c|}
\hline \multirow[b]{2}{*}{ Surfactant } & \multicolumn{2}{|c|}{ Virgin activated carbon } & \multicolumn{2}{|c|}{ Pre-treated activated carbon } & \multicolumn{2}{|c|}{ Modified activated carbon } & \multirow[b]{2}{*}{ References } \\
\hline & $\begin{array}{c}\text { BET specific } \\
\text { surface area }\left(\mathrm{m}^{2} / \mathrm{g}\right)\end{array}$ & $\begin{array}{c}\text { Micropore } \\
\text { volume }\left(\mathrm{cm}^{3} / \mathrm{g}\right)\end{array}$ & $\begin{array}{c}\text { BET specific } \\
\text { surface area }\left(\mathrm{m}^{2} / \mathrm{g}\right)\end{array}$ & $\begin{array}{c}\text { Micro pore } \\
\text { volume }\left(\mathrm{cm}^{3} / \mathrm{g}\right)\end{array}$ & $\begin{array}{c}\text { BET specific } \\
\text { surface area }\left(\mathrm{m}^{2} / \mathrm{g}\right)\end{array}$ & $\begin{array}{c}\text { Micropore } \\
\text { volume }\left(\mathrm{cm}^{3} / \mathrm{g}\right)\end{array}$ & \\
\hline CTAB & 888 & 0.376 & $901^{a}$ & $0.400^{\mathrm{b}}$ & $722^{c}$ & $0.310^{\mathrm{d}}$ & Mazarji et al. [27] \\
\hline SDBS & 158.1 & 0.0804 & $185.07^{\mathrm{e}}$ & $0.0937^{\mathrm{f}}$ & $131.4^{\mathrm{g}}$ & $0.0729^{\mathrm{h}}$ & Sun et al. [24] \\
\hline $\mathrm{CTABr}$ & 1407 & - & - & - & 608.9 & - & Allalou et al. [28] \\
\hline $\mathrm{CPC}$ & 822.7 & - & - & - & 608.9 & - & Farooq et al. [22] \\
\hline CTAB & 822.7 & - & - & - & 600.1 & - & Farooq et al. [22] \\
\hline CTAC & 822.7 & - & - & - & 571.3 & - & Farooq et al. [22] \\
\hline
\end{tabular}

${ }^{\mathrm{a}} \mathrm{BET}$ specific surface area after $\mathrm{NaOH}$ treatment, ${ }^{\mathrm{b}} \mathrm{Micropore}$ volume after $\mathrm{NaOH}$ treatment, ${ }^{\mathrm{c} B E T}$ specific surface area after $\mathrm{NaOH}$ treatment plus $\mathrm{CTAB}$ modification, ${ }^{\mathrm{e}} \mathrm{BET}$ specific surface area after $\mathrm{HNO}_{3}$ treatment, ${ }^{\mathrm{f}}$ Micropore volume after $\mathrm{HNO}_{3}$ treatment, ${ }^{\mathrm{g}} \mathrm{BET}$ specific surface area after $\mathrm{HNO}_{3}$ treatment plus SDBS modification, ${ }^{\mathrm{h}}$ Micropore volume after $\mathrm{HNO}_{3}$ treatment plus SDBS modification.

BET specific surface of $1407 \mathrm{~m}^{2} / \mathrm{g}$ reduced to $569 \mathrm{~m}^{2} / \mathrm{g}$ after CTAB modification. Similarly, Farooq et al. [22] observed that a virgin powdered activated carbon (PAC) with initial $822.7 \mathrm{~m}^{2} / \mathrm{g}$ BET specific surface area reduced to $608.9 \mathrm{~m}^{2} / \mathrm{g}$, $600.1 \mathrm{~m}^{2} / \mathrm{g}$ and $571.3 \mathrm{~m}^{2} / \mathrm{g}$ respectively after modification with $\mathrm{CPC}, \mathrm{CTAB}$ and CTAC.

However, treatment with $\mathrm{NaOH}$ or $\mathrm{HNO}_{3}$ prior to surfactant modification has been shown to minimise the reduction in the BET specific surface surface or micro pore volume and ultimately increase the net surface charge of the modified activated carbons. Mazarji et al. [27] recorded that the BET specific surface area and micro pore volume of a virgin activated carbon, $888 \mathrm{~m}^{2} / \mathrm{g}$ and $0.376 \mathrm{~cm}^{3} / \mathrm{g}$ increased to $901 \mathrm{~m}^{2} / \mathrm{g}$ and $0.400 \mathrm{~cm}^{3} / \mathrm{g}$ respectively after $\mathrm{NaOH}$ treatment but slightly reduced to $722 \mathrm{~m}^{2} / \mathrm{g}$ and $0.310 \mathrm{~cm}^{3} / \mathrm{g}$ after CTAB modification of the $\mathrm{NaOH}$ treated activated carbon. They obtained percentage nitrate removal of $\mathrm{NaOH}-\mathrm{CTAB}$ modified activated carbon, $80 \%$, $>\mathrm{NaOH}$-pre-treated activated carbon, $16 \%>$ virgin activated carbon, $8 \%$.

Similarly, Sun et al. [24] observed that the BET specific surface area and micro pore volume of a virgin activated carbon, $158 \mathrm{~m}^{2} / \mathrm{g}$ and $0.0804 \mathrm{~cm}^{3} / \mathrm{g}$ increased to $185.07 \mathrm{~m}^{2} / \mathrm{g}$ and $0.0937 \mathrm{~cm}^{3} / \mathrm{g}$ respectively after $\mathrm{HNO}_{3}$ treatment but reduced to $131.4 \mathrm{~m}^{2} / \mathrm{g}$ and $0.0729 \mathrm{~cm}^{3} / \mathrm{g}$ after SDBS modification. They obtained specific $\mathrm{Cd}$ (II) uptake with $\mathrm{HNO}_{3}$-SDBS modified activated carbon, $44.2 \mathrm{mg} / \mathrm{g}>\mathrm{SDBS}$ modified activated carbon, $26.6 \mathrm{mg} / \mathrm{g}>\mathrm{HNO}_{3}$ modified activated carbon, 22.8 $\mathrm{mg} / \mathrm{g}>$ virgin activated carbon, $6.78 \mathrm{mg} / \mathrm{g}$. The modified and activated carbons' performances seems to follow the same order as the net surface charge with $\mathrm{HNO}_{3}$-SDBS modified activated carbon, $-39.7>\mathrm{HNO}_{3}$ modified activated carbon, $-28.1>$ SDBS modified activated carbon, $-22.1>$ virgin activated carbon, -18.6 . Although there was an interchange in place between $\mathrm{HNO}_{3}$ modified activated carbon and SDBS modified activated carbon, nevertheless combination of $\mathrm{HNO}_{3}$ treatment with SDBS modification resulted into an increase in the net surface charge of the virgin activated carbon and enhancement in the adsorption capacity. 


\subsection{Sorption Mechanism of Surfactant Modified Activated Carbon}

Surface characterisation of virgin activated carbons shows that they have functional groups including carboxyl $(\mathrm{R}-\mathrm{COOH})$, phenolic $(\mathrm{R}-\mathrm{OH})$ and carbonyl $(\mathrm{R}=\mathrm{O})$ [23] [24]. The carbonyl group can complex with inorganic contaminant while the deprotonated acidic functional group can bind heavy metals ions. The possible mechanisms for anionic, SDS surfactant modified activated carbon used to remove bivalent cations from aqueous solution are as follows [23].

$$
\begin{gathered}
2 \mathrm{ROH}+\mathrm{M}^{2+} \leftrightarrow(\mathrm{RO})_{2} \mathrm{M}+2 \mathrm{H}^{+} \\
2 \mathrm{RCOOH}+\mathrm{M}^{2+} \leftrightarrow(\mathrm{RCOO})_{2} \mathrm{M}+2 \mathrm{H}^{+} \\
2 \mathrm{RSO}_{3} \mathrm{Na}+\mathrm{M}^{2+} \leftrightarrow 2 \mathrm{RSO}_{3} \mathrm{M}+2 \mathrm{Na}^{+} \\
\mathrm{RSO}_{3} \mathrm{Na}+\mathrm{H}^{2+} \leftrightarrow \mathrm{RSO}_{3} \mathrm{H}+\mathrm{Na}^{+}
\end{gathered}
$$

Equation (1) and Equation (2) indicate that cations can bind with little active binding groups present originally on the virgin activated carbon if they are not covered by the surfactant after modification. Equation (3) indicates that cations can bind with negatively charged group of the anionic surfactant anchored onto the surface of the activated carbon (ion exchange). Equation (4) indicates possible competitive or inhibition binding between cations and hydrogen ions with negatively charged group of the anionic surfactant.

Possibility of these reactions is further supported by the $\mathrm{pH}$ profile observed by Ahn et al. [23] during Cd (II) adsorption by surfactant modified and unmodified activated carbons. In the initial stage of the process there was a rapid drop in the $\mathrm{pH}$ of the system but the $\mathrm{pH}$ decrease in the virgin activated carbon system was greater than that of the surfactant modified activated carbon system. Similarly, the total acidity value obtained was: virgin activated carbon, 212.5 $\mu \mathrm{eq} / \mathrm{g}>\mathrm{SDS}$ modified activated carbon, $125 \mu \mathrm{eq} / \mathrm{g}$ or SDBS modified activated carbon, $125 \mu \mathrm{eq} / \mathrm{g}>$ DSS modified activated carbon, $176.8 \mu \mathrm{eq} / \mathrm{g}$. The decrease in the total acid was attributed to the surfactant coverage of the original functional groups on the virgin activated carbon.

Sun et al. [24] also observed total acidity of virgin activated carbon with 0.55 $\mathrm{mmol} / \mathrm{g}$ decreased to $0.45 \mathrm{mmol} / \mathrm{g}$ after SDSB modification. Of note is that $\mathrm{HNO}_{3}$ treatment of the virgin activated carbon increased its total acidity to 1.26 $\mathrm{mmol} / \mathrm{g}$ as expected due to introduction of more acidic functional group. Then subsequent modification with SDBS reduced the total acidity to $1.03 \mathrm{mmol} / \mathrm{g}$. This suggests that the acidic functional groups of the activated carbons were being deprotonated (dissociated) in water (Equation (1) and Equation (2)). Then, they observed a slight increase in the $\mathrm{pH}$ as the sorption continued. This could be due to binding of the protons onto the hydrophilic head group of anionic surfactant as shown in Equation (4) while Equation (3) confirms the increase in the specific uptake of Co (II) as contact time increased.

Possible adsorption mechanism for the uptake of anions by cationic modified activated carbons can also be made from empirical findings. Farooq et al. [22] 
reported that the amount of chloride ions, $\mathrm{Cl}^{-}$released by each of $\mathrm{CPC}-$ and CTACmodified activated carbonsafter the adsorption experiment deducted by the amount of chloride ions naturally released by each of them in the control experiments (only water) equals to bromate ions, $\mathrm{Bro}_{3}^{-}$removed by each of the modified activated carbons. This suggests that ion exchange is the main mechanism of adsorption of bromate ion, $\mathrm{Bro}_{3}^{-}$onto them. In contrast, the bromide ion, $\mathrm{Br}^{-}$released by the $\mathrm{CTAB}$ modified activated carbon wasslightly lower than the bromate, $\mathrm{Bro}_{3}^{-}$removed suggesting that the bromate removed in this system was partly by ion exchange and other mechanism such electrostatic interaction or surface complexation. Chen et al. [25] observed that chloride ions released by a CTAC modified activated carbon equals to $60 \%-83 \%$ of bromate removed.

Sometimes amount of counter anions exchanged varies with the initial concentration of the targeted anions. Tang et al. [21] reported that amount of chloride ions, $\mathrm{Cl}^{-}$released by CTACmodified activated carbon increased from 66 to $92 \%$ of perchlorate $\left(\mathrm{ClO}_{4}^{-}\right)$removed as perchlorate initial concentration increased from 0.1 to $0.4 \mathrm{mmol} / \mathrm{L}$. Similarly, $\mathrm{Xu}$ et al. [20] observed that chloride ion, $\mathrm{Cl}^{-}$released by CTACmodified activated carbon was $47 \%$ of perchlorate $\left(\mathrm{ClO}_{4}^{-}\right)$removed when perchlorate initial concentration was $0.0816 \mathrm{mmol} / \mathrm{L}$. Then increased to $77 \%$ of perchlorate $\left(\mathrm{ClO}_{4}^{-}\right)$removed as the initial perchlorate ranged from $0.1632-0.4897 \mathrm{mmol} / \mathrm{L}$. This suggests that ion exchange change from minor to main mechanism as the initial concentration of the targeted anions increased. And that other mechanism such as electrostatic attraction, physical adsorption or surface complexation possibly occurred along with ion exchange.

Overall, mechanisms of adsorption of cation (anion) onto activated carbon modified by anionic (cationic) surfactant include ion exchange, electrostatic attraction, physical adsorption or surface complexation depending on the quantity, activity and masking of the surface functional groups originally present on the virgin activated carbon before surfactant modification.

\section{Factors Affecting Efficiency of Surfactant Modified Activated Carbon}

Factors affecting percentage ion removed and/or specific ion uptake by surfactant modified activated carbon can be broadly categorised into environ mental factors and surfactant properties.

\subsection{Environmental Factors}

The environmental factors include process parameters such as initial concentation of contaminants, contact time, solution $\mathrm{pH}$, solution temperature, adsorbent concentration, ionic strength and competing ions.

\subsubsection{Solution $\mathrm{pH}$}

The $\mathrm{pH}$ of the sorbate solution is one of the key parameters affecting adsorption. 
It influences the net surface charge of the binding sites, solution chemistry of the target metal in terms of hydrolysis or complexation [30]. $\mathrm{pH}$ of the solution also contributes to metal precipitation, speciation and its availability for adsorption [31]. Isoelectric point $\mathrm{pH}\left(\mathrm{pH}_{\mathrm{IEP}}\right)$ or point of zero charge $\left(\mathrm{pH}_{\mathrm{PZC}}\right)$ is a useful guide to find an ideal $\mathrm{pH}$ for maximum inorganic contaminant uptake. This is the $\mathrm{pH}$ of the solution at which the net surface charge on the adsorbent equals zero. Solution $\mathrm{pH}$ above $\mathrm{pH}_{\mathrm{PZC}}$ makes the net surface charge on the adsorbent negative while solution $\mathrm{pH}$ below $\mathrm{pH}_{\mathrm{PZC}}$ makes the net surface charge positive [32]. Electrokinetic studies to estimate the isoelectric point $\mathrm{pH}\left(\mathrm{pH}_{\mathrm{IEP}}\right)$ is documented in the literature [33] [34].

The value of the zeta potential is used to characterise the net surface charge on an adsorbent. Positive zeta potential indicates positive net surface charge while negative zeta potential means negative surface charge. At every $\mathrm{pH}$ the zeta potential of cationic surfactant modified activated is always higher in positive value than the corresponding virgin activated carbons [20] [21] [22] while that of anionic surfactant usually higher in negative value than the corresponding virgin activated carbon [23] [35]. The zeta potential increases as the in initial concentration of cationic surfactant increases but remains constant above the critical micelle concentration of each surfactant [22].

$\mathrm{Xu}$ et al. [20] observed that perchlorate removed by virgin or CTACmodified activated carbon peaked at $\mathrm{pH} 2-3$ corresponding to their $\mathrm{pH}_{\mathrm{pzc}}(\mathrm{pH} 2$ for virgin activated carbon; $\mathrm{pH} 3$ for CTAC modified activated carbon). Below their $\mathrm{pH}_{\mathrm{pzc}}$ perchlorate specific uptake decreased as the $\mathrm{pH}$ decreased and above their $\mathrm{pH}_{\mathrm{pzc}}$ perchlorate specific uptake decreased as the $\mathrm{pH}$ increased. At every $\mathrm{pH}$ percentage removed by CTACmodified activated carbon consistently greater than virgin activated carbon.

Tang et al. [21] obtained $\mathrm{pH}_{\mathrm{pzc}} 4.3$ and 4.9 respectively for virgin activated carbon and CTAC modified activated carbon. The zeta potential of the CTACmodified activated carbon consistently higher in positive value at every $\mathrm{pH}$ indicating CTAC modified activated carbon has more positive surface charge than the virgin activated carbon. Within the $\mathrm{pH} 3-11$ range studied, specific perchlorate uptake by the virgin activated carbon decreased moderately from 9.8 $\mathrm{mg} / \mathrm{g}$ at $\mathrm{pH} 3$ to $\sim 7.8 \mathrm{mg} / \mathrm{g}$ at $\mathrm{pH} 11$. The specific perchlorate uptake by the CTAC modified activated carbon decreased rapidly from $27.31 \mathrm{mg} / \mathrm{g}$ at $\mathrm{pH} 3$ to $10.58 \mathrm{mg} / \mathrm{g}$ at $\mathrm{pH} 11$. Of note is that at each $\mathrm{pH}$ studied specific perchlorate uptake by CTAC modified activated carbon consistently greater than the virgin activated carbon. Other researchers obtained similar results [27] [28] [29].

Increase in the net negative surface charge of both virgin and cationic surfactantmodified activated carbon as $\mathrm{pH}$ increases causes repulsion between the negatively charged surface and the anions; hence reducing its uptake at such high $\mathrm{pH}$. In addition, the residual hydroxide ions, $\mathrm{OH}^{-}$produced due to higher $\mathrm{pH}$ compete with the targeted anions for binding on the adsorbent surface, thereby reducing the amount of anions removed. As $\mathrm{pH}$ decreases below 
$\mathrm{pH}_{\mathrm{pzc}}$, the net positive surface charge increases allowing more of the anions to be attracted onto the adsorbent surface. This usually increases the specific anions uptake by cationic modified activated carbon. However, excessive increase in the $\mathrm{pH}$ far below $\mathrm{pH}_{\mathrm{pzc}}$ reduced specific uptake of nitrate by CTAB modified activated carbon [28] and perchlorate by CTAC modified activated carbon [20] possibly due to repulsion between the protonated anions and positively charged amines groups on the cationic modified activated carbon [36].

Anionic surfactant modification enhances the net negative surface charge of virgin activated carbons [23] [24] and its surface become more negatively charged as the $\mathrm{pH}$ increases. Hence, adsorption of cations by anionic surfactant modified activated carbons increases with $\mathrm{pH}$ due to the attraction between the negatively charged surface and the targeted cations. For instance the specific $\mathrm{Cd}$ (II) uptake by DSS modified activated carbon, SDBS modified activated carbonand SDS modified activated carbonrespectively at $\mathrm{pH} 2$ were $0.065,0.075$, and $0.09 \mathrm{mmol} / \mathrm{g}$ but increased steadily to $0.13,0.140$ and $0.200 \mathrm{mmol} / \mathrm{g}$ at $\mathrm{pH} 6$ [23]. Of note is that the uptake by each of the anionic modified activated carbonswas greater than the virgin activated carbon at every $\mathrm{pH}$. This conforms to the observation of Kakavandi et al. [26] regarding the adsorption of Co (II) by virgin and SDSmodified activated carbon.

This behaviour was attributed partly to reduction in competition between $\mathrm{H}^{+}$ and Cd (II) for binding on the same sites as $\mathrm{pH}$ increases [37] [38]. In addition, increase in the net negative surface charge of the anionic modified surfactant as the $\mathrm{pH}$ increases causes attraction between the targeted cation and the negatively charged surface. However, excessive high $\mathrm{pH}$ should be avoided to prevent precipitation of metal hydroxide [23] [26]. The danger of microprecipitation starts at $\mathrm{pH}>5$ for lead and at $\mathrm{pH} 6.7$ for nickel [39]. Microprecipitation starts at $\mathrm{pH}>$ 6 for copper [40] [41], at $\mathrm{pH} 7$ for chromium [42] and at $\mathrm{pH}>8$ for cadium [43]. Formation of such insoluble precipitate may introduce errors into adsorption results as the removal of metal ions in the presence of such precipitate is not completely through binding on the surface function groups [44]. Occurrence of desorption of anionic surfactant anchored on the activated carbon is also high at a high $\mathrm{pH}[23]$.

\subsubsection{Initial Concentration}

Percentage inorganic contaminants removed by adsorbents usually decreases as initial ion concentration increases [26] [28] [45] [46] [47]. At low concentration of contaminant the available active binding sites are more than enough while at high initial concentration the binding sites are not enough; hence the percentage adsorbed will be higher at low initial concentration due to abundant available active bind sites compared to the number of targeted ions than at high initial concentration.

In contrast, adsorption capacity usually increases with increase in initial concentration [26] [28] [47] [48] [49]. This trend is the same for both cation adsorbed onto anionic surfactant modified activated carbon and anion adsorbed 
onto cationic surfactant modified activated carbon. For instance, Kakavandi et al. [26] observed that at $\mathrm{pH} 7,1.2 \mathrm{~g} / \mathrm{L}$ adsorbent concentration, $20^{\circ} \mathrm{C}, 200 \mathrm{rpm}$,

Co (II) specific uptake by SDS modified activated carbon increased from 16.4 to $40.8 \mathrm{mg} / \mathrm{g}$ while the percentage cation removed decreased from $98.2 \%$ to $49 \%$ as the initial Co (II) concentration increased from 20 to $100 \mathrm{mg} / \mathrm{L}$. Similarly, Allalou et al. [28] recorded an increase in the specific nitrate uptake from 32 to 80 $\mathrm{mg} / \mathrm{g}$ but decrease in percentage anion removed from $92 \%$ to $40 \%$ as the initial concentration increased from 100 to $600 \mathrm{mg} / \mathrm{L}$.

For a fixed mass of adsorbent, at low initial adsorbate concentration, active binding sites are under saturated but tend towards saturation as the initial concentration increases [28]. This will make the ratio of adsorbed concentration to initial concentration decreases as the initial adsorbate concentration increases [16]. However, increase in initial concentration increases the driving force causing more adsorbate to bind onto the adsorbent. Hence, for a fixed mass of adsorbent, increase in initial concentration of adsorbate increases the specific adsorbate uptake until equilibrium is attained [26] [27].

\subsubsection{Adsorbent Concentration}

Surfactant modified activated carbon concentration is another important factor affecting the percentage contaminant removed and the specific contaminant uptake. At constant adsorbate concentration, increase in concentration of the adsorbent increases the percentage contaminant removed but decreases the specific contaminant uptake.

Kakavandi et al. [26] at constant Co (II) initial concentration, recorded an increase in Co (II) removed from $51.3 \%$ to $95 \%$ but decrease in the specific ion uptake from 38.5 to $19 \mathrm{mg} / \mathrm{g}$ as SDS modified activated carbon concentration increased from 0.4 to $1.5 \mathrm{~g} / \mathrm{L}$. Similarly, Mazarji et al., [27] at constant $40 \mathrm{mg} / \mathrm{L}$ initial nitrate concentration obtained increase in percentage nitrate removed from $25 \%$ to $83 \%$ but a decrease in specific uptake from 11 to $3.3 \mathrm{mg} / \mathrm{g}$ as CTAB modified activated carbon concentration increased from 0.05 to $0.5 \mathrm{~g} / \mathrm{L}$.

Rising in percentage adsorbate could be attributed to more active binding sites and/or enhance surface area available as the adsorbent concentration increases for a fixed initial contaminant concentration [50] [51]. Reduction in the specific ion uptake with increase in adsorbent concentration could be due to unsaturation and/or lower exploitation of the active binding sites at high adsorbent concentration. In addition, at high adsorbent concentration particles are self-bound together and form aggregate; hence reduces the effective active binding sites available for adsorption. Therefore, the specific ion adsorbed reduces with increase in the adsorbent concentration [52] [53] [54].

\subsubsection{Contact Time}

Percentage contaminant removed and specific contaminant uptake by surfactant modified activated carbon usually increased with contact time until equilibrium. At optimum surfactant modification conditions, the adsorption capacity of the 
modified activated is usually greater than that of virgin activated carbon. However, adsorption rate of such modified activated carbons has no definite pattern. Surfactant modification could increase adsorption rate [22], reduce rate [25] [29] or maintain rate [28] when compared to virgin activated carbons.

Specifically, Farooq et al. [22] observed a decreasing order of adsorption rate of bromate onto various adsorbents as CTAC modified activated carbon > CPC modified activated carbon $>$ CTAB modified activated carbon $\approx$ virgin activated carbon. This suggests that bromate, $\mathrm{Bro}_{3}^{-}$exchange may occur rapidly with chloride counter ions, $\mathrm{Cl}^{-}$on CTAC and CPC than with bromide counter ion, $\mathrm{Br}^{-}$on the CTAB. Besides, increase in temperature of endothermic adsorption causes increase in rate of adsorption. For instance, pseudo second order rate constant of CTAC modified activated carbon increased from 0.0125 to 0.0311 $\mathrm{g} /(\mathrm{mg} \cdot \mathrm{min})$ as the solution temperature increased from $15^{\circ} \mathrm{C}$ to $60^{\circ} \mathrm{C}$ [21].

In contrast, Chen et al. [25] observed a decreasing adsorption rate after surfactant modification with virgin granular activated carbon adsorption rate $>$ CTAC modified activated carbon. Some researchers also obtained reduction in adsorption rate after modification with polymer [29]. Of note is that surfactant modification usually reduces the BET specific surface area of the modified activated carbon due to micropore blockage. Hence surface area and micro pore volume obtained by different authors after modification are different. In addition, the process parameters such solution temperature, solution $\mathrm{pH}$ and agitation rates used by different author differ. All these could contribute to different trends of adsorption rate observed by different authors.

Equilibrum times reported by different authors also differ. Allalou et al. [28] observed a rapid increase in percentage nitrate removed in the first 5 min contact. Their system attained equilibrium within $5 \mathrm{~min}$ of contact for both virgin activated carbon and the CTAB modified activated carbon. Similarly, specific perchlorate uptake adsorbed onto CTAC modified activated carbon increased rapidly in the first 15 min of contact accounting for $90 \%$ of the total perchlorate uptake but the equilibrium was attained in $30 \mathrm{~min}$ [21].

Of note is that some authors extend the contact time during isotherm studies above the equilibrium time obtained during kinetics studies. This explains a wide range (5 - $1440 \mathrm{~min}$ ) in the contact time listed in Table 1. For instance, Chen et al. [25] system attained equilibrium around $360 \mathrm{~min}$ but they used 1440 min as contact time for isotherm studies perhaps to ensure the maximum uptake that can be obtained for the modified activated carbon. In practice, rapid adsorption is most desired to allow a substantial reduction in the size of the adsorption column. This will make the process more cost effective.

\subsubsection{Solution Temperature}

Many authors conducted adsorption of inorganic contaminant onto surfactant modified activated carbon at ambient temperature [17] [23] [25] [28] [29]. However, few studies show that temperature has moderate effect on the percentage contaminant removed or specific contaminant uptake by the modified acti- 
vated carbons indicating the process is either endothermic or exothermic.

Tang et al. [21] observed that the specific perchlorate uptake by CTAC modified activated carbon increased from 35.5 to $55.3 \mathrm{mg} / \mathrm{g}$ as temperature increased from $25^{\circ} \mathrm{C}$ to $60^{\circ} \mathrm{C}$. They obtained positive change in enthalpy $(\Delta \mathrm{H})$ implying the adsorption is endothermic. Negative Gibb free energy $(\Delta \mathrm{G})$ was obtained indicating the adsorption is spontaneous. A positive entropy $(\Delta \mathrm{S}), 22 \mathrm{~J} /(\mathrm{mol} \cdot \mathrm{K})$ was obtained implying a net increase in randomness of perchlorate at the sol$\mathrm{id} /$ solution interface occurred in the internal structure of the adsorbent.

Cho et al. [29] recorded decrease in specific uptake from 29.4 and 77.2 to 24.4 and $56.6 \mathrm{mg} / \mathrm{g}$ respectively for both nitrate and $\mathrm{Cr}$ (VI) as temperature increased from $25^{\circ} \mathrm{C}$ to $45^{\circ} \mathrm{C}$. In addition, negative change in enthalpy $(\Delta \mathrm{H})$ and change in Gribb free energy $(\Delta G)$ were obtained for both ions indicating the process is exothermic and spontaneous. They also obtained a positive change in entropy $(\Delta \mathrm{S})$. Hence, operating such exothermic adsorption at ambient will save cost if this does not significantly reduce the adsorption rate.

\subsubsection{Ionic Strength}

Increase in ionic strength $(\mathrm{NaCl}$ concentration) suppresses ion exchange but enhances non-electrostatic (hydrophobic) attraction [55]. Hence, the net uptake of inorganic contaminant by surfactant modified activated carbons in the presence of $\mathrm{NaCl}$ depends on the dominant adsorption mechanism. For instance, Tang et al. [21] recorded a rapid decrease in specific perchlorate uptake by CTAC modified activated carbon from 24.8 to $18.4 \mathrm{mg} / \mathrm{g}$ as the $\mathrm{NaCl}$ concentration increased from 0 to $10 \mathrm{mmol} / \mathrm{L}$. Further increase in $\mathrm{NaCl}$ concentration to $50 \mathrm{mmol} / \mathrm{L}$ caused slight reduction to $18.06 \mathrm{mg} / \mathrm{g}$.

The rapid reduction could be explained by suppression of ion exchange between perchlorate, $\mathrm{ClO}_{4}^{-}$and CTAC on the surface of CTAC modified activated carbon suggesting that the main sorption mechanism by this system is ion exchange while the slight reduction at $50 \mathrm{mmol} / \mathrm{L} \mathrm{NaCl}$ could be explained by occurrence of non-electrostatic interaction accounting for the perchlorate adsorption at this region [55] [56]. In addition, competition between chloride ion, $\mathrm{Cl}^{-}$and perchlorate ions, $\mathrm{ClO}_{4}^{-}$for the same active binding sites on the adsorbent also contribute to the reduction in perchlorate adsorption with increase in ionic strength [56].

There is also an interaction between $\mathrm{NaCl}$ concentration and the contact timeon suppression of ion uptake by the surfactant modified activated carbon. $\mathrm{Xu}$ et al. [20] in the first $60 \mathrm{~min}$ of contact obtained increase in specific perchlorate uptake from 1.34 to $1.80 \mathrm{mg} / \mathrm{g}$ as the ionic strength increased from 0 to 1.71 $\mathrm{mmol} / \mathrm{L}$. Further increase in ionic strength to $8.55 \mathrm{mmol} / \mathrm{L}$ decreased the specific uptake to $1.54 \mathrm{mg} / \mathrm{g}$. The inhibition became significant at $120 \mathrm{~min}$ contact making the adsorption rate decreased from $46.35 \mathrm{~g} /(\mathrm{mmol} \cdot \mathrm{h})$ with no $\mathrm{NaCl}$ addition to 27.2 and $18.3 \mathrm{~g} /(\mathrm{mmol} \cdot \mathrm{h})$ respectively with addition of 1.71 and 8.55 $\mathrm{mmol} / \mathrm{L} \mathrm{NaCl}$. Pham et al. [57] observed similar results when using SDS modi- 
fied laterite to adsorb Copper (II) ion. They recorded increase in $\mathrm{Cu}^{2+}$ uptake from 150 to $185 \mathrm{mg} / \mathrm{g}$ as the ionic strength increased from 1 to $10 \mathrm{mmol} / \mathrm{L}$. But further increase to $50 \mathrm{mmol} / \mathrm{L} \mathrm{NaCl}$ caused reduction of uptake to $110 \mathrm{mg} / \mathrm{g}$. These results also suggest that electrostatic and non-electrostatic (hydrophobic) attraction mechanisms are occurring during adsorption of inorganic contaminants by surfactant modified activated carbon.

\subsubsection{Competing Ions}

Industrial effluents hardly contain single inorganic ion. The co-ions will compete with the targeted ions for binding sites if they have preference for the same sites [58]. Chen et al. [25] added a varied (0.049 - $159.2 \mathrm{mg} / \mathrm{L})$ of perchlorate, nitrate, sulphate or phosphate ions to a fixed bromate concentration $(0.1 \mathrm{mg} / \mathrm{L})$ to study its effect on the specific bromate uptake by CTAC modified activated carbon. The competing co-ions' inhibitory effect is insignificant at 10:1 co-ions to bromate molar ratio. This could be due to abundant active binding site at such low concentration. However, perchlorate and nitrate's inhibition became significant at 100:1 co-ions to bromate molar ratio while sulphate and phosphate's inhibition became significant at 1000:1 co-ions to bromate molar ratio. At the same co-ions to bromate molar ratio, competition followed decreasing order of $\mathrm{ClO}_{4}^{-}>\mathrm{NO}_{3}^{-}>\mathrm{SO}_{4}^{2-}>\mathrm{PO}_{4}^{3-}$. This order suggests that competition decreases as valence electrons increase. Other researcher observed similar results [59].

Mazarji et al. [27] also studied the effect of adding each of phosphate, carbonate, sulphate and chloride on the specific nitrate uptake by $\mathrm{NaOH}-\mathrm{CTAB}$ modified activated carbon. The co-ions concentrations were varied from 20 to 160 $\mathrm{mg} / \mathrm{L}$ while nitrate was fixed at $40 \mathrm{mg} / \mathrm{L}$. Addition of each of the co-ions significantly reduced the specific nitrate uptake. Competition followed a decreasing order of $\mathrm{SO}_{4}^{2-}>\mathrm{Cl}^{-}>\mathrm{PO}_{4}^{3-}>\mathrm{CO}_{3}^{2-}$. The least effect of phosphate and carbonate was attributed to formation of $\mathrm{H}_{2} \mathrm{CO}_{3}$ and $\mathrm{H}_{2} \mathrm{PO}_{4}^{-}$species which have less degree of competing with nitrate for active binding sites.

\subsection{Surfactant Properties}

Type of surfactant and surfactant concentration also contribute to the overall effectiveness of the modified activated carbons for adsorption of cations or anions from aqueous solution.

\subsubsection{Type of Surfactant}

Surfactant can be broadly classified into anionic, cationic and non-ionic. The targeted ion determines the type of surfactant required for modifying the activated carbon. This is because investigation into the mechanism of adsorption of ions by a surfactant modified activated carbon suggests that ion exchange is usually the main mechanism [21] [22] while other mechanism such electrostatic attraction, surface complexation and physical adsorption do complete it [23] [25]. Hence, if anion is the targeted contaminant to be removed from the aqueous solution, proper cationic surfactant is required for the modification of the activated 
carbon [17] [21] [22] [27] [28] [29]. In contrast, if cation is the targeted contaminant, then proper anionic surfactant should be selected for the modification [23] [24] [26]. The flexibility in anchoring of surfactant onto the surface of activated carbon makes it one of the appealing surface modification methods.

\subsubsection{Surfactant Concentration}

The surfactant concentration used for modification of activated carbon also contributes to its adsorption capacity. Chen et al. [25] varied CTAC concentration from 0.2 to $8 \mathrm{mmol} / \mathrm{L}$ to obtain the proper surfactant concentration that maximise the uptake capacity of the modified activated carbon. The specific bromate uptake peaked at $2 \mathrm{mmol} / \mathrm{L}$, equivalent to $1.26^{*}$ critical micelle concentration of CTAC, below which the specific uptake steadily reduced and above which the specific uptake equally reduced.

Similarly, Kakavandi et al. [26] varied the SDS concentration from 0.5 to $5^{\star} \mathrm{CMC}$ in order to optimise the specific Co (II) uptake by SDS modified activated carbon. The Co (II) removed peaked at $1.5^{\star} \mathrm{CMC}$ of SDS, below and above which the specific uptake reduced steadily reaching the least value, $0 \%$ at $5^{\star} \mathrm{CMC}$. Of note is that at $6 \mathrm{~h}$ (optimised time) the specific uptake of the modified activated carbon for all concentration except $5^{\star} \mathrm{CMC}$ were greater than that produced by virgin activated carbon.

Adsorption capacity of cationic or anionic surfactant modified activated carbon increase as surfactant concentration increases due to enhancement in their net surface positive or negative charge respectively. However, net surface charge of cationic surfactant modified activated carbons did not increase significantly beyond their CMC [22] while the surface area reduce [22] [24] [27] [28] due to surfactant blockage of micropores [24] [27]. This explains the reduction in specific ion uptake observed by Chen et al. [25] and Kakavandi et al. [26] with excessive increase in surfactant concentration above their CMC.

In addition, reduction of the micro-pore volume above CMC has high tendency of masking the active binding sites originally present on the virgin activated carbon thereby reducing their contribution to physical adsorption, surface complexation and electrostatic interaction to the main ion exchange. Few researchers fixed surfactant concentration below CMC [17] [27] or above CMC [21] during adsorption experiments. Such approach may prevent optimising the capacity of the modified activated carbons.

\subsection{Activated Carbon Pre-Treatment}

Alkali $(\mathrm{NaOH})$ and acid $\left(\mathrm{HNO}_{3}\right)$ are the common reagents for treating activated carbon before surfactant modification to enhance their adsorption capacity.

\subsubsection{Alkaline Pre-Treatment}

Mazarji et al. [27] observed that treatment of activated carbon with $\mathrm{NaOH}$ at $75^{\circ} \mathrm{C}$ for $7 \mathrm{~h}$ prior to CTAB surfactant modification enhances its adsorption for nitrate. They obtained percentage nitrate removed as $\mathrm{NaOH}-\mathrm{CTAB}$ modified ac- 
tivated carbon, $80 \%>\mathrm{NaOH}$ treated activated carbon, $16 \%>$ virgin activated carbon, $8 \%$. The observed enhancement was attributed to the increase in the specific surface area and micro pore volume caused by $\mathrm{NaOH}$ treatment. More micro pores allowed anchoring of more CTAB thereby increasing the net positive surface charge [60]. Increase in micro pores could increase nitrate uptake via hydrophobic interaction such as physical adsorption, surface complexation and non-electrostatic interaction [61]. $\mathrm{NaOH}$ pre-treatment improves removal/solubility of most organic components attached to virgin activated carbon into water by weakening their attractive van der Waals forces [24].

\subsubsection{Acid Pre-Treatment}

Sun et al. [24] treated activated carbon with $\mathrm{HNO}_{3}$ before modification with sodium dodecyl benzene sulfonate (SDBS) to optimise its Cd (II) adsorption. $\mathrm{HNO}_{3}$ concentration was varied from $0.5-4 \mathrm{~mol} / \mathrm{L}$, temperature, $60^{\circ} \mathrm{C}-100^{\circ} \mathrm{C}$, and SDBS, 5000 - 40,000 mg/L. The specific Cd (II) uptake by the $\mathrm{HNO}_{3}$-SDBS modified activated carbon peaked at $3.29 \mathrm{~mol} / \mathrm{L} \mathrm{HNO}_{3}, 76^{\circ} \mathrm{C}$ and $30,700 \mathrm{mg} / \mathrm{L}$ SDBS. They observed that interaction of $\mathrm{HNO}_{3}$ and surfactant concentration produced most significant effect on the maximum Cd (II) uptake capacity. The specific Cd (II) uptake capacity order obtained are $\mathrm{HNO}_{3}$-SDBS modified activated carbon, $44.2 \mathrm{mg} / \mathrm{g}>\mathrm{SDBS}$ modified activated carbon, $26.60 \mathrm{mg} / \mathrm{g}>\mathrm{HNO}_{3}$ modified activated carbon, $22.78 \mathrm{mg} / \mathrm{g}>$ virgin activated carbon, $6.78 \mathrm{mg} / \mathrm{g}$. Of note is that the developed surface area, functional groups, and more net negative surface charge responsible for the higher adsorption capacity show by the HNO3-SDBS modified activated carbon.

\section{Leaching of Surfactant Modified Carbon}

Stability or leaching of surfactant modified activated carbon in aqueous solution should be considered during selection. This is important to ensure effluent quality and minimise secondary contaminants via surfactant desorption. Mazarji et al. [27] reported that CTAC did not leach in the lifetime of NaOH-CTAC modified activated carbon used. Tang et al. [21] also reported that CTAC modified activated carbon show good stability in water having $1.83 \%$ and $1.98 \%$ of the total CTAC loaded onto the activated carbon respectively leached in 2 and 32 days leaching test.

In contrast, Parette et al. [62] observed that $0.6 \%-21 \%$ of the total amount of dicocodimethyl ammonium chloride, tallowtrimethyl ammonium chloride, cetyltrimethyl ammonium chloride leached out of the tailored carbon bed. However, virgin activated carbon polishing bed used to chase the tailored bed significantly reduced the leached surfactant below detection limits.

\section{Regeneration}

Regeneration of spent (saturated) modified activated carbons will minimise disposal. It will also make the process more environmental friendly, preserve our resources and more cost effective. Findings show that surfactant modified acti- 
vated carbon can be regenerated. Cho et al. [29] desorbed nitrate and Cr (VI) ions from a saturated cationic (polymer) modified activated carbon using $0.05 \mathrm{M}$ $\mathrm{NaOH}$ (equivalent to $\mathrm{pH}$ 12.7). The modified reagent is cationic quaternary ammonium-containing polymer, [3-(methacryloylamino)propyl]-trimethylammonium chloride (CPMG) having similar property as cationic surfactant.

The specific nitrate uptake by the CPMG for the three consecutive adsorption/desorption cycles reduced from $21.4 \mathrm{mg} / \mathrm{g}$ (for the fresh CPMG-activated carbon) to $19.4,15.9$, and $14.9 \mathrm{mg} / \mathrm{g}$ respectively. The regeneration efficiencies were $90.7 \%, 82 \%$, and $93.7 \%$ respectively. The specific $\mathrm{Cr}$ (VI) uptake by the CPMG reduced from $59 \mathrm{mg} / \mathrm{g}$ (for the fresh CPMG-activated carbon) to 51.8 , 49.3 and $45.5 \mathrm{mg} / \mathrm{g}$ respectively. The regeneration efficiencies were $87.8 \%, 95.2 \%$ and $92.3 \%$ respectively. At the $0.05 \mathrm{M} \mathrm{NaOH}$ (equivalent to $\mathrm{pH} 12.7$ ) the net surface charge on the CPMG-activated carbon will be negative which will enhance desorption of the adsorbed negatively charges nitrate and Cr (VI) ions.

Tang et al. [21] used $1 \mathrm{M} \mathrm{HCl}$ instead of $\mathrm{NaOH}$ to desorb perchlorate adsorbed to CTAC modified activated carbon. The specific perchlorate uptake of the fresh CTAC modified activated carbon was $24.06 \mathrm{mg} / \mathrm{g}$. This value reduced to 23.07, $21.01,19.12$ and $18.99 \mathrm{mg} / \mathrm{g}$ respectively after four consecutive adsorption/regeneration cycles. The regeneration efficiencies were $95.88 \%, 91.46 \%$, $90.62 \%$ and $99.32 \%$ respectively. Of note is that they obtained pHpzc for this CTAC modified activated carbon as 4.8 and the equivalent $\mathrm{pH}$ of $1 \mathrm{M} \mathrm{HCl}$ used regeneration is $\mathrm{pH} 0$, indicating highly acidic. The net surface charge of this adsorbent will be highly positive at this highly acid $\mathrm{pH}$ which ordinarily should enhance adsorption of the negatively charged perchlorate ion. The probable reason for the desorption observed could be due to protonation of perchlorate which will increase the repulsion between the adsorption perchlorate ions and the positively charged surface.

\section{Conclusions}

Surfactant concentration used for modification of activated carbon contributes to its specific contaminant uptake. The modified activated carbon usually shows maximum contaminant uptake around its critical micelle concentration.

Well-developed micro pores are required to allow anchoring of enough surfactant for high net surface charge and to minimise reduction in the specific surface area/micro pores volume after surfactant modification. Hot $\mathrm{NaOH}$ or $\mathrm{HNO}_{3}$ treatment prior to surfactant modification has been shown to minimise surface area reduction and/or increase net surface charge of the modified activated carbons.

Solution $\mathrm{pH}$ is one of the key environmental parameters affecting adsorption capacity of the modified activated carbons and its variation can be used for regenerating the spent (saturated) modified activated carbon. Adsorption capacity of cationic modified activated carbon for targeted anion increases with decrease 
in $\mathrm{pH}$ below $\mathrm{pH}_{\mathrm{pzc}}$ but decreases with increase in $\mathrm{pH}$ above $\mathrm{pH}_{\mathrm{pz}}$. Adsorption capacity of anionic modified activated carbon for targeted cation increases with increase in $\mathrm{pH}$ above $\mathrm{pH}_{\mathrm{pzc}}$ but decreases with decrease in $\mathrm{pH}$ below $\mathrm{pH}_{\mathrm{pzc}}$.

Overall, surfactant modification is a simple but efficient method of enhancing adsorption capacity of activated carbons for removing anions or cations from aqueous solution. However, a handful publication is available on the regeneration of the spent (saturated) surfactant modified activated carbons. Hence, more research efforts should be directed towards proper reagents and the optimised conditions such as contact time, concentration, and temperature for regenerating such modified activated carbons.

\section{Conflicts of Interest}

The author declares no conflicts of interest regarding the publication of this paper.

\section{References}

[1] Tchounwou, P.B., Yedjou, C.G., Patlolla, A.K. and Sutton, D.J. (2012) Heavy Metals Toxicity and the Environment. EXS, 101, 133-164.

https://doi.org/10.1007/978-3-7643-8340-4_6

[2] Urbansky, E.T. and Schock, M. (1999) Issues in Managing the Risks Associated with Perchlorate in Drinking Water. Journal of Environmental Management, 56, 79-95. https://doi.org/10.1006/jema.1999.0274

[3] Kim, S.J., Lee, K.Y., Lee, K.C., Chung, N. and Jung, D.I. (2012) Effect of General ions on Biological Treatment of Perchlorates in Smelting Wastewater. Desalination and Water Treatment, 48, 60-69. https://doi.org/10.1080/19443994.2012.698795

[4] US EPA (2009) National Primary Drinking Water Regulations. United States Environmental Protection Agency EPA 816-F-09-004, May 2009.

[5] Korom, S.F. (1992) National Denitrification in the Saturated Zone: A Review. Water Resources Research, 28, 1657-1668. https://doi.org/10.1029/92WR00252

[6] Nolan, B.T., Ruddy, B.C., Hitt, K.J. and Helsel, D.R. (1997) Risk of Nitrate in Groundwaters of the United States-A National Perspective. Environmental Science \& Technology, 31, 2229-2236. https://doi.org/10.1021/es960818d

[7] WWAP (United Nations World Water Assessment Programme) (2017) The United Nations World Water Development Report 2017. Wastewater: The Untapped Resource. UNESCO, Paris.

[8] Atkinson, B.W., Bux, F. and Kasan, H.C. (1998) Considerations for Application of Biosorption Technology to Remediate Metal-Contaminated Industrial Effluents. Water SA., 24, 129-135.

[9] Crini, G. (2006) Non-Conventional Low-Cost Adsorbents for Dye Removal: A Review. Bioresource Technology, 97, 1061-1085. https://doi.org/10.1016/j.biortech.2005.05.001

[10] Sulaymon, A.H., Mohammed, A.A. and Al-Musawi, T.J. (2013) Competitive Biosorption of Lead, Cadmium, Copper, and Arsenic Ions Using Algae. Environmental Science and Pollution Research, 20, 3011-3023. https://doi.org/10.1007/s11356-012-1208-2

[11] Gray, N.F. (1999) Water Technology. John Wiley and Sons, New York.

[12] Huang, Y.C. and Koseoglu, S.S. (1993) Separation of Heavy Metals from Industrial 
Waste Streams by Membrane Separation Technology. Waste Management, 13, 481-501. https://doi.org/10.1016/0956-053X(93)90079-C

[13] Zhou, P., Huang, J., Alfred, W.F. and Wei, S. (1999) Heavy Metals Removal from Wastewater in Fluidized Bed Reactor. Water Research, 33, 1918-1924. https://doi.org/10.1016/S0043-1354(98)00376-5

[14] Kermani, M., Izanloo, H., Kalantary, R.R., Barzaki, H.S. and Kakavandi, B. (2017) Study of the Performances of Low-Cost Adsorbents Extracted from Rosa Damascena in Aqueous Solutions Decolorization. Desalination and Water Treatment, 80, 357-369. https://doi.org/10.5004/dwt.2017.21019

[15] Jafari, A.J., Kakavandi, B., Kalantary, R.R., Gharibi, H., Asadi, A., Azari, A., Babaei, A.A. and Takdastan, A. (2016) Application of Mesoporous Magnetic Carbon Composite for Reactive Dyes Removal: Process Optimization Using Response Surface Methodology. Korean Journal of Chemical Engineering, 33, 2878-2890. https://doi.org/10.1007/s11814-016-0155-x

[16] Azari A., Babaie, A.A., Rezaei-Kalantary, R., Esrafili, A., Moazzen, M. and Kakavandi, B. (2014) Nitrate Removal from Aqueous Solution by Carbon Nanotubes Magnetized with Nano Zero-Valent Iron. Journal of Mazandaran University of Medical Sciences, 23, 15-27.

[17] Choi, H.-D., Jung, W.-S., Cho, J.-M., Ryu, B.-G., Yang, J.-S. and Baek, K. (2009) Adsorption of $\mathrm{Cr}(\mathrm{VI})$ onto Cationic Surfactant-Modified Activated Carbon. Journal of Hazardous Materials, 166, 642-646. https://doi.org/10.1016/j.jhazmat.2008.11.076

[18] Monser, L. and Greenway, G.M. (1996) Liquid Chromatographic Determination of Methylamines Using Porous Graphitic Carbon. Analytica Chimica Acta, 322, 63-68. https://doi.org/10.1016/0003-2670(95)00606-0

[19] Monser, L. and Adhoum, A. (2002) Modified Activated Carbon for the Removal of Copper, Zinc, Chromium and Cyanide from Wastewater. Separation and Purification Technology, 26, 137-146. https://doi.org/10.1016/S1383-5866(01)00155-1

[20] Xu, J.-H., Gao, N.-Y., Deng, Y., Sui, M.-H. and Tang, Y.-L. (2011) Perchlorate Removal by Granular Activated Carbon Coated with Cetyltrimethyl Ammonium Chloride. Desalination, 275, 87-92. https://doi.org/10.1016/j.desal.2011.02.036

[21] Tang, D., Yang,N., Yang,Y., Zhang, X., Xiao, W., Wang, D., Mao, X. and Alshawabkeh, A.N. (2014) Enhanced Adsorption of Aqueous Perchlorate on Quaternary Ammonium Chloride Surfactant-Modified Activated Carbon Fibers. Desalination and Water Treatment 55, 1-12.

[22] Farooq, W., Hong, H.-J., Kim, E.J. and Yang, J.-W. (2012) Removal of Bromate $\left(\mathrm{BrO}_{3}\right)$ from Water Using Cationic Surfactant-Modified Powdered Activated Carbon (SM-PAC). Separation Science and Technology, 47, 1906-1912. https://doi.org/10.1080/01496395.2012.664232

[23] Ahn, C.K., Park, D., Woo, S.H. and Park, J.M. (2009) Removal of Cationic Heavy Metal from Aqueous Solution by Activated Carbon Impregnated with Anionic Surfactants. Journal of Hazardous Materials, 164, 1130-1136.

https://doi.org/10.1016/j.jhazmat.2008.09.036

[24] Sun, H., He, X., Wang, Y., Cannon, F.S., Wen, H. and Li, X. (2018) Nitric Acid-Anionic Surfactant Modified Activated Carbon to Enhance Cadmium(II) Removal from Wastewater Preparation Conditions and Physicochemical Properties. Water Science \& Technology, 78, 1489-1498. https://doi.org/10.2166/wst.2018.424

[25] Chen, W.-F., Zhang, Z.-Y., Li, Q. and Wang, H.-Y. (2012) Adsorption of Bromate and Competition from Oxyanions on Cationic Surfactant-Modified Granular Activated Carbon (GAC). Chemical Engineering Journal, 203, 319-325. 
https://doi.org/10.1016/j.cej.2012.07.047

[26] Kakavandi, B., Alireza Raofi, A., Peyghambarzadeh, S.M., Ramavandi, B., Nirib, M.H. and Ahmadib, M. (2018) Efficient Adsorption of Cobalt on Chemical Modified Activated Carbon: Characterization, Optimization and Modeling Studies. Desalination and Water Treatment, 111, 310-321. https://doi.org/10.5004/dwt.2018.22238

[27] Mazarji, M., Aminzadeh, B., Baghdadi, M. and Bhatnagar, A. (2017) Removal of Nitrate from Aqueous Solution Using Modified Granular Activated Carbon. Journal of Molecular Liquids, 233, 139-148. https://doi.org/10.1016/j.molliq.2017.03.004

[28] Allalou, Q., Miroud, D., Belmedani, M. and Sadaoui, Z. (2018) Performance of Surfactant-Modified Activated Carbon Prepared from Dates Wastes for Nitrate Removal from Aqueous Solutions. Environmental Progress \& Sustainable Energy, Online.

[29] Cho, D.-W., Chon, C.-M., Kim, Y., Jeon, B.-H., Schwartz, F.W., Lee, E.-S. and Song, H. (2011) Adsorption of Nitrate and Cr(VI) by Cationic Polymer-Modified Granular Activated Carbon. Chemical Engineering Journal, 175, 298-305. https://doi.org/10.1016/j.cej.2011.09.108

[30] Fiol, N., Villaescusa, I., Martinez, M., Miralles, N., Poch, J. and Serarols, J. (2006) Sorption of $\mathrm{Pb}(\mathrm{II}), \mathrm{Ni}(\mathrm{II}), \mathrm{Cu}(\mathrm{II})$ and $\mathrm{Cd}(\mathrm{II})$ from Aqueous Solution by Olive Stone Waste. Separation and Purification Technology, 50, 132-140. https://doi.org/10.1016/j.seppur.2005.11.016

[31] Esposito, A., Pagnanell, F. and Veglio, F. (2002) PH-Related Equilibria Models for Biosorption in Single Metal Systems. Chemical Engineering Science, 57, 307-313. https://doi.org/10.1016/S0009-2509(01)00399-2

[32] Farooq, U., Kozinski, J.A., Khan, M.A. and Athar, M. (2010) Biosorption of Heavy Metal Ions Using Wheat Based Biosorbents-A Review of the Recent Literature. Bioresource Technology, 101, 5043-5053. https://doi.org/10.1016/j.biortech.2010.02.030

[33] Cayllahua, J.E.B., de Carvalho, R.J. and Torem, M.L. (2009) Evaluation of Equilibrium, Kinetic and Thermodynamic Parameters for Biosorption of Nickel(II) Ions onto Bacteria Strain Rhodococcus opacus. Minerals Engineering, 22, 1318-1325. https://doi.org/10.1016/j.mineng.2009.08.003

[34] Bueno, B.Y.M., Torem, M.L., Molina, F. and de Mesquita, L.M.S. (2008) Biosorption of Lead(II), Chromium(III) and Copper(II) by $R$. opacus. Equilibrium and Kinetic Studies. Minerals Engineering, 21, 65-75. https://doi.org/10.1016/j.mineng.2007.08.013

[35] Basar, C.A., Karagunduz, A., Keskinler, B. and Cakici, A. (2003) Effect of Presence of Ions on Surface Characteristics of Surfactant Modified Powdered Activated Carbon (PAC). Applied Surface Science, 218, 169-174.

[36] Xu, X., Gao, B., Yue, Q., Li, Q. and Wang, Y. (2013) Nitrate Adsorption by Multiple Biomaterial Based Resins: Application of Pilot-Scale and Lab-Scale Products. Chemical Engineering Journal, 234, 397-405.

https://doi.org/10.1016/j.cej.2013.08.117

[37] Youssef, A.M., El-Nabarawy, T. and Samra, S.E. (2004) Sorption Properties of Chemically Activated Carbons. 1. Sorption of Cadmium(II) Ions. Colloids and Surfaces A: Physicochemical and Engineering Aspects, 235, 153-163. https://doi.org/10.1016/j.colsurfa.2003.12.017

[38] Qiu, Y., Cheng, H., Xu, C. and Sheng, D. (2008) Surface Characteristics of Crop-Residue-Derived Black Carbons and Lead(II) Adsorption. Water Research, 
42, 567-574. https://doi.org/10.1016/j.watres.2007.07.051

[39] Britton, H.T.S. (1943) The Application of Electrometric Methods to the Study of Some Ionic Reactions. Annual Reports on the Progress of Chemistry, 40, 43-59.

[40] Elliott, H.A. and Huang, C.P. (1981) Adsorption Characteristic of Some Cu(II) Complexes on Alumino Silicates. Water Research, 15, 849-855. https://doi.org/10.1016/0043-1354(81)90139-1

[41] Asmal, M., Khan, A.H., Ahmad, S. and Ahmad, A. (1998) Role of Sawdust in the Removal of Copper(II) from Industrial Wastes. Water Research, 32, 3085-3091. https://doi.org/10.1016/S0043-1354(98)00067-0

[42] Blazquez, G., Hernainz, F., Calero, M., Martn-Lara, M.A. and Tenorio, G. (2009) The Effect of $\mathrm{pH}$ on the Biosorption of $\mathrm{Cr}(\mathrm{III})$ and $\mathrm{Cr}(\mathrm{VI})$ with Olive Stone. Chemical Engineering Journal 148, 473-479. https://doi.org/10.1016/j.cej.2008.09.026

[43] Lodeiro, P., Barriada, J.L., Herrero, R. and Sastre de Vicente, M. (2006) The Marine Macroalga Cystoseira baccata as Biosorbent for Cadmium(II) and Lead(II) Removal: Kinetic and Equilibrium Studies. Environmental Pollution, 142, 264-273. https://doi.org/10.1016/j.envpol.2005.10.001

[44] Volesky, B. and Holan, Z.R. (1995) Biosorption of Heavy Metals. Biotechnology Progress, 11, 235-250. https://doi.org/10.1021/bp00033a001

[45] Arivalagan, P., Singaraj, D., Haridass, V. and Kaliannan, T. (2014) Removal of Cadmium from Aqueous Solution by Batch Studies Using Bacillus Cereus. Ecological Engineering, 71, 728-735. https://doi.org/10.1016/j.ecoleng.2014.08.005

[46] Oves, M., Khan, M.S. and Zaidi, A. (2013) Biosorption of Heavy Metals by Bacillus thuringiensis Strain OSM29 Originating from Industrial Effluent Contaminated North Indian Soil. Saudi Journal of Biological Sciences, 20, 121-129. https://doi.org/10.1016/j.sjbs.2012.11.006

[47] Bai, R.S. and Abraham, T.E. (2001) Biosorption of Cr(VI) from Aqueous Solution by Rhizopus nigricans. Bioresource Technology, 79, 73-81. https://doi.org/10.1016/S0960-8524(00)00107-3

[48] Cheng, J., Yin, W., Chang, Z., Lundholm, N. and Jiang, Z. (2016) Biosorption Capacity and Kinetics of Cadmium(II) on Live and Dead Chlorella vulgaris. Journal of Applied Phycology, 29, 211-221. https://doi.org/10.1007/s10811-016-0916-2

[49] Horsfall Jr., M. and Spiff, A.I. (2005) Effect of Metal Ion Concentration on the Biosorption of $\mathrm{Pb}^{2+}$ and $\mathrm{Cd}^{2+}$ by Caladium bicolor (Wild Cocoyam). African Journal of Biotechnology, 4, 191-196.

[50] Ahmadi, M., Foladivanda, M., Jaafarzadeh, N., Ramezani, Z., Ramavandi, B., Jorfi, S. and Kakavandi, B. (2017) Synthesis of Chitosan Zero-Valent Iron Nanoparticles-Supported for Cadmium Removal: Characterization, Optimization and Modeling Approach. Journal of Water Supply: Research and Technology, 66, 116-130. https://doi.org/10.2166/aqua.2017.027

[51] Jafari, A.J., Kakavandi, B., Kalantary, R.R., Gharibi, H., Asadi, A., Azari, A., Babaei, A.A. and Takdastan, A. (2016) Application of Mesoporous Magnetic Carbon Composite for Reactive Dyes Removal: Process Optimization Using Response Surface Methodology. Korean Journal of Chemical Engineering, 33, 2878-2890. https://doi.org/10.1007/s11814-016-0155-x

[52] Pasandideh, E.K., Kakavandi, B., Nasseri, S, Mahvi, A.H., Nabizadeh, R, Esrafili, A. and Kalantary, R.R. (2016) Silica-Coated Magnetite Nanoparticles Core-Shell Spheres $\left(\mathrm{Fe}_{3} \mathrm{O}_{4} @ \mathrm{SiO}_{2}\right)$ for Natural Organic Matter Removal. Journal of Environmental Health Science and Engineering, 14, 21. 
https://doi.org/10.1186/s40201-016-0262-y

[53] Babaei, A.A., Kakavandi, B., Rafiee, M., Kalantarhormizi, F., Purkaram, I., Ahmadi, E. and Esmaeili, S. (2017) Comparative Treatment of Textile Wastewater by Adsorption, Fenton, UV-Fenton and US-Fenton Using Magnetic Nanoparticles-Functionalized Carbon (MNPs@C). Journal of Industrial and Engineering Chemistry, 56, 163-174. https://doi.org/10.1016/j.jiec.2017.07.009

[54] Kalantry, R.R., Jafari, A.J., Esrafili, A., Kakavandi, B., Gholizadeh, A. and Azari, A. (2016) Optimization and Evaluation of Reactive Dye Adsorption on Magnetic Composite of Activated Carbon and Iron Oxide. Desalination and Water Treatment, 57, 6411-6422. https://doi.org/10.1080/19443994.2015.1011705

[55] Hu, Y., Guo, T., Ye, X., Li, Q., Guo, M., Liu, H. and Wu, Z. (2013) Dye Adsorption by Resins: Effect of Ionic Strength on Hydrophobic and Electrostatic Interaction. Chemical Engineering Journal, 228, 392-397.

https://doi.org/10.1016/j.cej.2013.04.116

[56] Vermohlen, K., Lewandowski, H., Narres, H.D. and Schwuger, M. (2000) Adsorption of Polyelectrolytes onto Oxides-The Influence of Ionic Strength, Molar Mass, and $\mathrm{Ca}^{2+}$ Ions. Colloids and Surfaces A, 163, 45-53.

https://doi.org/10.1016/S0927-7757(99)00429-X

[57] Pham, T.D., Nguyen, H.H., Nguyen, N.V., Vu, T.T., Pham, T.N.M., Doan, T.H.Y., Nguyen, M.H. and Ngo, T.M.V. (2017) Adsorptive Removal of Copper by Using Surfactant Modified Laterite Soil. Journal of Chemistry, 2017, Article ID: 1986071. https://doi.org/10.1155/2017/1986071

[58] Mack, C., Wilhelmi, B., Duncan, J.R. and Burgess, J.E. (2007) Biosorption of Precious Metals. Biotechnology Advances, 25, 264-271.

https://doi.org/10.1016/j.biotechadv.2007.01.003

[59] Hong, H.J., Kim, H., Baek, K. and Yang, J.W. (2008) Removal of Arsenate, Chromate, and Ferricyanide by Cationic Surfactant Modified Powdered Activated Carbon. Desalination, 223, 221-228. https://doi.org/10.1016/j.desal.2007.01.210

[60] Patterson, J., Parette, R., Cannon, F.S., Lutes, C. and Henderson, T. (2011) Competition of Anions with Perchlorate for Exchange Sites on Cationic Surfactant-Tailored GAC. Environmental Engineering Science, 28, 249-256. https://doi.org/10.1089/ees.2010.0075

[61] Bhatnagar, A., Ji, M., Choi, Y., Jung, W., Lee, S., Kim, S.S., Lee, G., Suk, H., Kim, H., Min, B., Kim, S.S., Jeon, B. and Kang, J. (2008) Removal of Nitrate from Water by Adsorption onto Zinc Chloride Treated Activated Carbon. Separation Science and Technology, 43, 886-907. https://doi.org/10.1080/01496390701787461

[62] Parette, R. and Cannon, F.S. (2005) The Removal of Perchlorate from Ground Water by Activated Carbon Tailored with Cationic Surfactants. Water Research, 39, 4020-4028. https://doi.org/10.1016/j.watres.2005.07.024 